\title{
4 European Integration and Extraterritorial Protection
}

NeCESSARY DELIMITATION of the Common Market or seclusionist fortification against an imaginary invasion? The story of integration in the field of immigration and asylum can be told in many different ways. Rather than adding to an impressive collection of exhaustive linear accounts ${ }^{293}$, we would like to proceed in three distinct steps, starting out with a macro perspective and ending with the presentation of single legal instruments.

To our mind, three different layers should be discerned when telling the story of integration: the real world, the institutional world and the normative world. With the real world, we mean actual events impacting

${ }^{293}$ Comprehensive accounts are readily available elsewhere. See E. Guild, 'The impetus to harmonise: asylum policy in the European Union', in F. Nicholson and P. Twomey (eds), Refugee Rights and Realities. Evolving International Concepts and Regimes (1999, Cambridge University Press, Cambridge) (covering developments until the conclusion of the Treaty of Amsterdam); T. Brübach, Die Zusammenarbeit der Mitgliedstaaten der Europäischen Union auf dem Gebiet Inneres und Justiz, unter besonderer Berïcksichtigung der Asyl- und Einwanderungspolitik sowie der polizeilichen Zusammenarbeit (1997, Shaker Verlag, Aachen) (covering the period until the 1996 IGC); C. Klos, Rabmenbedingungen und Gestaltungsmöglichkeiten der Europäischen Migrationspolitik (1998, Hartung-Gorre Verlag, Konstanz), pp. 27-87 (covering developments until the conclusion of the Treaty of Amsterdam). 


\section{CHAPTER 4}

on migration and the demand for protection, such as the outbreak of conflict and the advent of refugee crises. Below, a brief overview of the realities of flight to European host countries will be given, in the attempt to reflect some pertinent changes in this layer. Next, there is the institutional world: it comprises single states and state groupings, notably the EC, the EU and the Schengen Group. Further on in this chapter, we shall track the development of the institutional setting from Schengen to Amsterdam in greater detail. By means of these institutional structures, Member States have created norms in reaction to the real world layer: the acquis communautaire on asylum and migration. ${ }^{294}$ The subsequent three chapters shall be dedicated exclusively to this normative layer: the instruments spawned by the integration process shall be expounded in a subject-related order, starting with access to territory and finishing with the issue of return.

For this as well as the following chapter, we would like to beg acceptance for a temporal limitation from 1985-99, a period spanning over two highly symbolic events, albeit on different levels: the White Paper of the Commission on the Completion of the Common Market ${ }^{295}$ and the Kosovo intervention. Notably, four segments seem to recur more often than others: 1985 to 1989,1989 to 1992,1992 to 1997 and 1997 to 1999. We shall attempt to structure the following narrative around these four segments.

\footnotetext{
${ }^{294}$ At this stage, it might be appropriate to define what is meant by the term 'acquis communautaire'. As the concept is a flexible one, and its content changes as any other legal codification, we choose to delimit it as follows. The aquis communautaire on asylum and migration shall be what the Council of the Euopean Union considers it to be at any given point in time. The instruments belonging to the acquis are listed in: Council of the European Union, Draft list of the 'acquis' of the Union and of its Member States in the field of Justice and Home Affairs, 20 March 1998, Doc. No. 6437/2/98 REV 3 [hereinafter Draft List] and in the Addendum to this document [hereinafter Draft List Addendum]. Those parts of the list relevant for asylum issues are reproduced in P. J. van Krieken, The Asylum Acquis Handbook (2000, T.M.C. Asser Press, The Hague), pp. 86-98.

295 European Commission, Completing the Internal Market. White Paper from the Commission to the European Council, $\mathrm{COM}(85) 310$ final [henceforth White Paper].
} 


\subsection{The Real World: Flight Movements to and within Europe since 1985}

Let us recap the development of flight and displacement in the real world. ${ }^{296}$ With the benefit of hindsight, the period 1985-9 must be regarded as relatively peaceful for host states in Western Europe. Certainly, the number of protection seekers was on the rise, but the Eastern borders of the EC and the transit routes leading to them were still managed by a cordon sanitaire of socialist states exercising rigorous exit control. ${ }^{297}$

This would change with the dismantling of the Iron Curtain in the period from 1989-92, making physical access from Central and Eastern European countries to Member States of the EU easier. Mobility augmented not only for citizens of these states, but for transiting refugees from other parts of the world as well. After a decade of steady growth, the number of asylum applications took a sharp turn upwards at the end of the eighties. Within the EC, applications increased almost tenfold in the period between 1985 and 1992. ${ }^{298}$ The peak of protection claims in 1992 was unprecedented in the post-war period: almost 700000 persons sought refuge in European countries. ${ }^{299}$

296 The following does not purport to give a full overview of the complex migrational realities in the period 1985-99. For a survey of asylum migration to the EU, see A. Böcker and T. Havinga, Asylum Migration to the European Union: Patterns of Origin and Destination (1998, European Commission, Luxembourg). For a thorough presentation of forced migration and flight movements, see UNHCR, The State of the World's Refugees 1993 (1993, Penguin, New York); UNHCR, The State of the World's Refugees 1995. In Search of Solutions (1995, OUP, Oxford); and UNHCR, The State of the World's Refugees 1997-98. A Humanitarian Agenda (1997, OUP, Oxford). For patterns of migration in general, see UN Commission on Population and Development, World Population Monitoring, 1997. Issues of international migration and development: selected aspects, 20 December 1996, UN Doc. No. ESA/P/WP.132. For a historical account of flight and refuge throughout the $20^{\text {th }}$ century, see T. Kushner and K. Knox, Refugees in an Age of Genocide (1999, Frank Cass, London).

297 However, these borders were sometimes permeable for transiting protection seekers. By way of example, the German Democratic Republic allowed Lebanese protection seekers to transit through its territory en route to Sweden in the early Eighties. See H. Quaritsch, Recht auf Asyl. Studien zu einem missdeuteten Grundrecht (1985, Duncker \& Humblot, Berlin), p. 24.

${ }^{298}$ By the end of 1992, the Member States hosted some 1.2 million refugees of a world refugee population comprising almost 19 million people. UNHCR, 1993, pp. 151-3.

299 Source: IGCARMP, 1997, p. 21. 


\section{CHAPTER 4}

The 1992 statistics indicate that the majority of protection seekers originated from European countries, one of the main causes being the conflict in Former Yugoslavia, flaring since $1991{ }^{300}$ The implications of this conflict for migration and protection in Europe can hardly be overestimated, and it certainly represents the decisive event of the 1992-7 period. For the first time since the Hungarian crisis in 1956, Western Europe was confronted with a substantial outflow of Europeans. ${ }^{301}$ Soon, the focus of the conflict moved to Bosnia, which dominated the migrational agenda well beyond the Dayton peace agreement in 1995. While Germany sent a first wave of Bosnians back as early as 1996, other countries waited until 1997 before phasing in return movements. ${ }^{302}$

In the 1997-9 period, Bosnia gave way to Kosovo. After a successive build-up of aggression and persecution, the conflict erupted in early 1999, forcing a wave of over 800000 protection seekers to seek refuge abroad. Kosovo differed from Bosnia in three respects. First, NATO intervened with considerable military resources, expressly pursuing the aim of stopping further displacement and creating the conditions for return of those already displaced. Second, deflection proved to be much more effective than it had been during the Bosnian crisis. After all, the majority of Kosovars were displaced internally or were hosted in Albania and the Former Yugoslav Republic of Macedonia. Third, attempts to share the receptive burden surfaced. Considerable resources were sent from Western Europe to the regional host countries, and a limited evacuation programme was launched to exonerate Macedonian refugee camps.

On the numerical level, one may state that the real world layer brought a moderate rise in protection claims between 1985-98 and a steep rise to an unprecedented peak between 1989 and 1992. A decline followed, and in

300 A survey of ten European countries shows that in 1992, $35 \%$ of asylum applications were made by nationals of former Yugoslavia (Austria, Belgium, Denmark, France, Germany, the Netherlands, Norway, Sweden, Switzerland and the United Kingdom), UNHCR, 1993, pp. 37, 158.

301 The conflict in the former Yugoslavia exceeded the 1956 Hungarian outflow by a factor of five. European Commission, Explanatory Memorandum to the Proposal to the Council for a Joint Action adopted by the Council on the basis of Article K.3 2 (b) of the Treaty on European Union concerning Temporary Protection of Displaced Persons, 4 March 1997, p. 2, para. 2.

302 For an overview of the return policies and practices by EU Member States with regard to Bosnians, see R. Black, K. Koser and M. Walsh, Conditions for the return of displaced persons from the European Union: Final report. 1998 (1998, European Commission, Luxembourg). 
1995 the numbers had fallen below the 1989 level again. The period 19979 saw rising demands, mostly due to the conflict in Kosovo. Beyond mere statistics, Western Europeans had to realize that they could no longer profit from the control exercised by the socialist regimes in the East: borders had become permeable, and the dismantling of state structures had led to the first large-scale refugee crises in decades. In that sense, 1989 and 1992 are pivotal dates for the history of refugee protection in Europe.

\subsection{The Institutional World: From Schengen to Amsterdam}

Parallel to the changing dynamics of flight in the period from 1985 to 1999 , a reinforcement and diversification of multilateral institutions seized with migration and protection issues took place. ${ }^{303}$ While both issues belonged-and still belong-to the domaine reservée for autonomous policy decisions by single European states, prudent preparations for a greater measure of multilateralism were made. We shall track this development in the process of European integration by highlighting five steps: the 1985 White Paper, the Schengen process, the European Political Cooperation, the Maastricht Treaty and, finally, the Treaty of Amsterdam.

${ }^{303}$ Taking a wider perspective, this diversification can be tracked in other arenas as well. One may point at the decision of a number of industrialized states to sever parts of the discourse on migration and protection from the universal forum offered by UNHCR, and to start their own private discussion club by launching IGCAMRP in 1985. IGCAMRP offers states an environment where protection concerns occupy a more subordinate role than at UNHCR, and the perspectives of the South are largely excluded. 


\section{CHAPTER 4}

\subsubsection{Freedom through Control: The 1985 White Paper and the Single European Act}

Although the harmonization of asylum systems in different European states had seized the Council of Europe for quite a while ${ }^{304}$, it was the emerging Common Market without internal border control that inspired serious work on common rules regarding asylum issues. Institutionally, this relocated the initiative from the Council of Europe to the EC Member States. Materially, it brought the issues of asylum and protection under the heading of migration control.

For almost thirty years, the objective of free movement of persons had been a near-comatose item on the agenda of European integration. With the beginning of the eighties, the political process aiming at the realization of the internal market started to gain momentum. ${ }^{305}$ The 1985 White Paper on the Completion of the Internal Market ${ }^{306}$ was probably the most elaborate expression of this process. It attempted to offer a blueprint for the next seven years of integration, with completion of the internal market envisaged for the year 1992. The White Paper laid down the goal of the complete abolishment of internal border controls ${ }^{307}$ and pointed out that asylum law and the situation of refugees had to be considered in the discussion on measures compensating for the loss of control due to their abolishment. ${ }^{308}$

The thrust of the Commission White Paper was mirrored in the Single European $\mathrm{Act}^{309}$, adopted a year later. Two features of the SEA merit underscoring. First, an express provision confirmed the political

\footnotetext{
304 Back in the Seventies and the early Eighties, the Council of Europe had already taken issue with harmonization aspects. See, e.g., Recommendation 787 (1976) on Harmonization of Eligibility Practice; Recommendation R (1981) 16 on the Harmonization of National Procedures Relating to Asylum. For an overview of harmonization efforts within the Council of Europe in that phase, albeit with a somewhat particularist bias on state interests, see K. Hailbronner, Möglicbkeiten und Grenzen einer europäischen Koordinierung des Einreise- und Asylrechts. Ihre Auswirkungen auf das Asylrecht der Bundesrepublik Deutschland (1989, Nomos Verlagsgesellschaft, BadenBaden), pp. 27-34.

${ }^{305}$ For developments preceding the White Paper, see Brübach, 1997, pp. 2-15.

306 See note 295 above.

307 White Paper, para. 27.

308 White Paper, para 11.

309 Single European Act, 9 September 1985, OJ (1987) L 169/1.
} 
determination of Member States to complete the internal market by 1992. ${ }^{310}$ Second, the Member States laid down the following statement in the Final Act of the SEA.

In order to promote the free movement of persons, the Member States shall cooperate, without prejudice to the powers of the Community, in particular as regards the entry, movement and residence of nationals of third countries. ${ }^{311}$

The form of such co-operation would continue to be outside the institutional framework of the EC until the Maastricht Treaty. The quoted statement was without prejudice to the sovereign powers of the Member States in the named areas. ${ }^{312}$ Nonetheless, it flags that the message of the Commission White Paper had been heard and approved by the Member States: no internal market without measures on the movement of non-communitarians. Or, more succinctly: freedom had to be attained through the means of control. Thus, it has to be understood that the European harmonization of asylum law was never intended to be a comprehensive solution to the problems of refugee protection. It was conceived as a technical consequence of the abolition of internal borders. To a significant degree, this heritage still haunts the contemporary acquis.

\subsubsection{L'Europe accélérée: Schengen}

Meanwhile, pioneering work in the area of free movement was being done by a small integrationist elite. 1985 sees the birth of l'Europe à deux vitesses: an avant-garde of five EC Member States signs the Schengen Agreement ${ }^{313}$, drawing up a framework for the abolishment of internal border controls

310 See Art. 8a (1) TEC. In a declaration on Art. 8a, the Member States clarified that the specification of a date for the completion of the common market would not imply a legal obligation.

311 Final Act, Political Declaration by the Governments of the Member States on the Free Movement of Persons, annexed to the Single European Act. OJ (1987) L 169/26.

${ }^{312}$ General Declaration on Articles 13 to 19 of the Single European Act. Annexed to the Final Act of the Single European Act, OJ (1987) L 169/25. See also Brübach, 1997, pp. $18-9$.

313 Agreement between the Governments of the States of the Benelux Economic Union, the Federal Republic of Germany and the French Republic on the Gradual Abolition of Checks at their Common Borders, June 14, 1985 [hereinafter Schengen Agreement]. 


\section{CHAPTER 4}

and the adoption of compensatory measures. This instrument introduced a number of concrete measures facilitating cross-border traffic among Contracting Parties and established a work programme for the complete abolishment of internal borders among its Contracting Parties. Among the necessary compensatory measures, the harmonization of visa policies and of certain areas of domestic aliens legislation was listed. ${ }^{314}$

Five years of negotiations on the topics of immigration, police and justice co-operation, drug policy and information exchange followed. Finally, a document subsequently known as the Schengen Convention ${ }^{315}$ was signed by Belgium, France, Germany, Luxembourg and the Netherlands. Its normative core is contained in Article 2 SC, stating that the internal borders of Contracting Parties may be passed at any point without any checks on persons being carried out. As compensatory measures, the Schengen Convention contains inter alia provisions on the control of external borders, on visa requirements, on the responsibility for the processing of asylum applications, on information exchange under the so-called Schengen Information System (SIS) and on the introduction of carrier sanctions. The Convention provided for its own institutional framework by arranging for an Executive Committee ${ }^{316}$ and endowing it with the power to issue detailed and binding regulations on a number of issues. Under its Rules of Procedure, the Executive Committee was presumed to meet under seclusion of the public ${ }^{317}$, and its deliberations and votes were covered by the duty of confidentiality. ${ }^{318}$ Moreover, it was capable of deciding that its own decisions-which could very well have a binding effect and impact on individual rights or obligations-were

\footnotetext{
314 Art. 20 of the Schengen Agreement.

315 Convention applying the Schengen Agreement of 14 June 1985 between the Governments of the States of the Benelux Economic Union, the Federal Republic of Germany and the French Republic on the Gradual Abolition of Checks at their Common Borders, 19 June 1990 [hereinafter Schengen Convention, abbreviated SC].

316 Under Chapter VII SC.

317 Schengen Executive Committee, Rules of Procedure of the Executive Committee established pursuant to Title VII of the Agreement implementing the Schengen Agreement, 18 October 1993, Art. 3 (1).

318 Ibid., Art 2 (1).
} 
confidential. ${ }^{319}$ The opaqueness of procedures and the amount of secrecy engulfing the Committee's work provoked harsh criticism and were brandished as a 'democratic retrogression'. ${ }^{320}$ It is noteworthy that the executive powers of the Schengen Committee were not balanced by any judicial review through the ECJ, and that its secretive modus operandi largely precluded corrections by domestic or supranational parliaments.

A lengthy ratification process as well as complex technical preparations protracted the implementation of the Schengen Convention after its formal entry into force on 1 September 1993. Following a decision by the Executive Committee ${ }^{321}$, the instrument has been applied since 26 March 1995. ${ }^{322}$ A number of Schengen States have concluded bilateral agreements with each other to facilitate the practical implementation of the Convention. ${ }^{323}$

319 Curtin and Meijers quote a particularly absurd example of the secrecy policies within the Schengen Committee. On the demand of a single Member State (Germany), a decision on a common list of countries whose nationals must be in possession of a visa for entering Schengen states was classified as confidential. Thus, it was impossible for any outsider observer-e.g. a citizen of a Schengen state-to determine whether or not the imposition of visa requirements stemmed from international obligations under the Schengen Convention. D. Curtin and H. Meijers, 'The Principle of Open Government in Schengen and the European Union: Democratic Retrogression?', in B. G. Tahzib, C. Groenendijk, M. Vreugdenhill-Klap and J. M. van de Put (eds,), Democracy, Migrants and Police in the European Union: The 1996 IGC and Beyond (1997, FORUM, Utrecht), p. 23.

320 Curtin and Meijers, 1997, pp. 19-28.

321 According to a declaration to Art. 139 SC by the Schengen Parties, the Convention would only enter into force if external border controls functioned properly. The smooth operation of SIS would be a precondition, too. In the light of the technical difficulties, the Executive Committee decided that the entry into force should take place on 26 March 1995. See K. Würz, Das Schengener Durchführungsübereinkommen: Einführung, Erläuterungen, Vorscbriften (1997, Boorberg, Stuttgart), p. 30.

322 Starting with that date, the Schengen Convention was only applied in seven countriesthe five original contracting parties, Portugal and Spain. The other Schengen Members were to join successively, upon satisfaction of the technical requirements for the implementation of the Schengen acquis. The starting date of the Convention's implementation in a certain country is determined by unanimous decision of the Executive Committee.

${ }^{323}$ Such agreements have been concluded between a large number of Schengen states. See e.g. Accord relatif aux articles 40 et 41 de la Convention d'application de l'Accord de Schengen du 14.6.1985, relatif à la suppression graduelle des controles aux frontières communes du 19.6.1990, JO 1995, p. 16445; Accord relatif aux articles 2 et 3 de l'Accord d'adhésion du Royaume d'Espagne á la Convention d'application de l'Accord de Schengen du 14.6.1985, relatif à la suppression graduelle des controles aux frontières communes du 19.6.1990, JO 1995, p. 16445. 


\section{CHAPTER 4}

It must be emphasized that both the Schengen Agreement and the Schengen Convention are products of intergovernmental co-operation outside the Community framework. Community institutions were not involved in the drafting process. Nonetheless, the same bureaucrats were involved in the Community process and in the Schengen process. Therefore, it is hardly surprising that the Schengen Group in many respects seemed to act upon the analysis presented in the Commission White Paper of 1985. And normative coherence with the Community framework was an explicit goal for the Schengen avant-garde; the Schengen Convention contains a savings clause for EC law in Article 134 SC.

By and by, the avant-garde project went mainstream. Successively, additional Member States acceded to both Schengen instruments. ${ }^{324}$ Accession Protocols and Agreements were signed with Italy (on 27 November 1990), Spain and Portugal (25 June 1991), Greece (on 6 November 1992), Austria (on 28 April 1995) and Denmark, Finland and Sweden (on 19 December 1996). Ireland and the United Kingdom remained outside, however, denying the Schengen co-operation full congruence with the group of EU Member States. Institutional convergence was reached in 1997, when the Schengen acquis ${ }^{325}$ was incorporated into the framework of the European Union by means of a Protocol to the Treaty of Amsterdam ${ }^{326}$, taking into account the outsider role of Ireland and the United Kingdom. ${ }^{327}$ Concurrently, the role of the Schengen Executive Committee was taken over by the Council of the European Union.

To preserve the free movement of persons already attained among the Scandinavian states by virtue of the Nordic Passport Union, Iceland and Norway were associated to the implementation of the Schengen acquis. ${ }^{328}$ This implied that both countries were to handle external border controls on behalf of the Schengen Group.

324 According to Art. 140 (2) SC, a prerequisite for accession is membership in the European Union.

325 On the precise content of the Schengen acquis, see chapter 4.2.6 below.

326 Protocol integrating the Schengen acquis into the framework of the European Union, annexed to the Treaty on European Union and to the Treaty establishing the European Community, 6 October 1997, Doc. No. CONF 4007/97, TA/P/en 5, [hereinafter Schengen Protocol].

${ }^{327}$ See chapter 4.2.7 below.

${ }^{328}$ See text accompanying note 420 below. 


\subsubsection{Trying to Catch Up: The European Political Cooperation}

\subsubsection{The Dublin Convention}

It would be wrong to depict the phase from 1985-92 as solely dominated by the avant-garde activism of the Schengen countries. The Twelve were pursuing the same track, albeit at a slower pace, within the noninstitutionalized framework of the European Political Co-operation (henceforth EPC). The vehicle of this co-operation was the Council of EC Immigration Ministers and, on a subsidiary level, the Ad-Hoc-Group on Immigration ${ }^{329}$; its prime product was the Dublin Convention. ${ }^{330}$ The Dublin Convention was signed by all Member States on 15 June 1990, and is still the core instrument in the area of asylum and migration law. Unlike the much broader Schengen Convention, the Dublin Convention deals exclusively with the allocation of asylum applications. Its allocation criteria are largely identical with those laid down as the Schengen Convention, and can be historically traced to an unsuccessful Draft Agreement stemming from discussions within the Council of Europe. ${ }^{331}$ The Dublin Convention represents a gain over the Schengen Convention thanks to its expanded geographical scope, comprising all EU Member States.

To avoid normative conflicts between the two Conventions, Contracting Parties to the Schengen Convention signed the so-called

329 Further on the organisational aspects of the Council and the Ad-hoc Group on Immigration, see Klos, 1998, pp. 32-7; Brübach, 1997, p. 27-33.

330 Convention Determining the State Responsible for Examining Applications for Asylum Lodged in One of the Member States of the European Communities, 15 June 1990 [hereinafter Dublin Convention].

331 CAHAR drew up a Draft Agreement on responsibility for examining asylum requests in 1988. With some minor deviations, this draft features the same allocation principles which were to be used in the Schengen and Dublin Conventions. A German-language version of the Draft agreement is reprinted in Hailbronner, 1989, pp. 228-32. Within the Council of Europe, disagreement on the Draft was considerable-countries of the South feared that the Draft agreement would shift reception burdens onto them (for a description of the various positions taken by states, see Hailbronner, 1989, pp. 29-31). With the benefit of hindsight, one may claim that these fears turned out to be entirely justified, as shown in chapter 8.4.1 below. 


\section{CHAPTER 4}

Bonn Protocol. ${ }^{332}$ The Protocol provided that the rules on the responsibility for asylum applications laid down in Chapter VII SC were no longer applicable with the entry into force of the Dublin Convention. ${ }^{333}$

After the final ratification by the Republic of Ireland, the Dublin Convention entered into force on 1 September 1997. It remains an instrument of international law, outside the EC framework. Precisely as the Schengen Convention has done, the Dublin Convention triggered the conclusion of bilateral agreements between Member States to facilitate its implementation. ${ }^{334}$ We shall have reason to revert to the details of the Dublin Convention and of the instruments related to it in a later chapter. ${ }^{335}$

\subsubsection{The Draft External Border Convention}

Beyond the Dublin Convention, the Ad-hoc Group on Immigration also elaborated a draft for a convention on the crossing of external borders ${ }^{336}$, which mirrored the approach taken in the Schengen Convention. In addition, the draft featured norms on access to the territory of Member States based on humanitarian grounds or on international obligations. ${ }^{337}$ Nonetheless, due to a conflict between Spain and the U.K. on the status of Gibraltar, the draft never reached the signature stage.

332 Protokoll zu den Konsequenzen des Inkrafttretens des Dubliner Übereinkommens für einige Bestimmungen des Durchführungsübereinkommens zum Schengener Übereinkommen, Bonn, 26 April 1994, BGBl II 1995, pp. 737-8 [hereinafter Bonn Protocol].

333 See Art. 1 of the Bonn Protocol, stating that provisions in Title II Chapter VII SC as well as the definition of the terms 'application for asylum', 'applicant for asylum' and 'processing of an application for asylum' in Art. 1 SC shall no longer be applicable.

334 See, e.g., the German-Swedish agreement, determining the modalities of readmission, and the precedence of the Dublin Convention over an older readmission agreement between the two countries: Överenskommelse med Tyskland angäende tillämpningen av konventionen den 15 juni 1990 rörande bestämmandet av den ansvariga staten för prörning av en ansökan om asyl som framställts $i$ en av medlemsstaterna $i$ Europeiska gemenskaperna (SÖ 1997:4), Stockholm 19 November and 9 December 1998, SÖ 1998:28.

${ }^{335}$ See chapter 5.2.1.1 below.

336 Brübach, 1997, pp. 31-2. The Draft Convention has not been published.

${ }^{337} \mathrm{~J}$. Ketelsen, 'Die Zuständigkeit der EG für die Schaffung eines EG-Asylrechts nach Maastricht', in K. Barwig, G. Brinkmann, B. Huber, K. Lörcher and C. Schumacher (eds), Asyl nach der Änderung des Grundgesetzes (1994, Nomos, Baden-Baden), p. 358. 
On 10 December 1993, the Commission presented a proposal based on Article K.3 TEU/Maastricht establishing the Convention on the crossing of the external frontiers of the Member States. ${ }^{338}$ The content of this proposal was largely identical to that of the aforementioned draft, but it was never adopted. Now, with the entry into force of the Amsterdam Treaty and the integration of the Schengen acquis into the Union framework, the situation has changed. Ireland and the United Kingdom can now easily opt in with regard to the Schengen acquis. ${ }^{339}$ Hence, the negotiation and conclusion of a treaty largely mirroring the Schengen Convention has become superfluous.

\subsubsection{Enter Soft Law: The London Resolutions}

In the year before Maastricht would change the institutional framework of integration, the EPC launched four non-binding instruments in the field of asylum and migration. This step marked the debut of soft law as a steering instrument in this field. The texts dealt with

manifestly unfounded applications for asylum;

the concept of safe third countries;

the concept of safe countries of origin; and

O the expulsion of illegal third country nationals. ${ }^{340}$

They have collectively become known as the 'London resolutions'. The content of these instruments shall be expounded contextually in later chapters. ${ }^{341}$

338 European Commission, Proposal for a decision based on Article K.3 of the Treaty on European Union establishing the Convention on the crossing of the external frontiers of the Member States, 10 December 1993, COM(93)684 final.

339 See chapter 4.2.7 below.

${ }^{340}$ See text accompanying notes 585,625 , and 640 below.

${ }^{341}$ See chapters 6.1, 5.2.2.1 and 7.2.1 below. 


\section{CHAPTER 4}

\subsubsection{Swapping Information: CIREA and CIREFI}

In the same year, the EC Immigration Ministers added an institutional layer to their co-operation by establishing the Centre for Information, Discussion and Exchange on Asylum (henceforth CIREA) ${ }^{342}$ and Centre for Information, Discussion and Exchange on the Crossing of Frontiers and Immigration (henceforth CIREFI) ${ }^{343}$, two fora of information exchange in asylum and migration matters. ${ }^{344}$

CIREFI was assigned to collate intelligence on the crossing of Member States' external borders, inter alia serving as an early warning mechanism for the inflow of undocumented migrants. According to its present mandate, CIREFI shall 'assist the Member States in effectively studying legal immigration preventing illegal immigration and unlawful residence, in effectively combating immigration crime, in better detecting forged documents and in improving expulsion practice'. ${ }^{345}$

CIREA, on the other hand, was tasked with the collection of information on the situation in countries of origin $^{346}$, which was well in line with the provision on mutual information exchange enshrined in the Dublin Convention $^{347}$ and in the London resolution dealing with safe

${ }^{342}$ Decision of 11 June 1992 setting up the CIREA (Centre for Information, Discussion and Exchange on Asylum), WGI 1107 (The acronym CIREA stems from the body's French name).

${ }^{343}$ EC Ministers responsible for immigration, Decision of 30 November and 1 December 1992 to establish a Centre for Information, Discussion and Exchange on the Crossing of Frontiers and Immigration (CIREFI). This instrument has not been published in the Official Journal.

${ }^{344}$ Since 1998, information on countries of origin is also collated within the High Level Working Group on Migration and Asylum. See text accompanying note 761 below.

${ }^{345}$ Council of the European Union, Conclusions of 30 November 1994 on the organization and development of the Centre for Information, Discussion and Exchange on the Crossing of Frontiers and Immigration (CIREFI), OJ (1996) C 274/50, pp. 50-1, para. 1.

${ }^{346}$ For a comparison of CIREA and other bodies dealing with asylum information within the EU, see Advisory Council on International Affairs, Asylum Information and the European Union (1999, AIV, The Hague), focusing inter alia on sources used, the degree of public access and the impact of collected information on asylum procedures.

347 See Art. 14 DC. 
countries of origin. ${ }^{348}$ Its information sources are the governments of Member States and the European Commission, and the information collated by it is in principle only accessible to the bodies directly involved in determination procedures at the administrative and ministerial levels. ${ }^{349}$ It discharges its tasks by compiling so-called 'joint reports' on the situation in countries of origin, based on guidelines drawn up by the Council. ${ }^{350}$

Although its function is primarily a consultative one, it cannot be excluded that CIREA's assessment of the situation in countries of origin may have a critical impact on the outcome of protection claims in Member States. CIREA documents are largely confidential, which blocks external screening of how it performs its tasks. ${ }^{351}$ As sceptics have pointed out, this may put protection seekers and their lawyers at a considerable disadvantage, as they do not know whether and to what extent a decision on an individual protection claim has been affected by information passed on through CIREA. ${ }^{352}$ However, it is quite evident that Member States themselves do not consider their common data collection exercises as

348 EC Ministers responsible for immigration, Conclusions adopted on 30 November 1992 on countries in which there is generally no serious risk of persecution, WGI 1281 [henceforth SCO Conclusions]. Para. 2 states inter alia that 'Member States have the goal to reaching [sic!] common assessment of certain countries that are of particular interest in this context. To this end, Member States will exchange information within an appropriate framework on any national decisions to consider particular countries as ones in which there is generally no serious risk of persecution'.

European Parliament, Asylum in the European Union: The 'Safe Country of Origin Principle' (1997, The European Parliament, Brussels), p. 24. Council of the European Union, Circulation and confidentiality of joint reports on the situation in certain third countries, 20 June 1994, OJ (1996) C 274/43.

350 Council of the European Union, Guidelines for joint reports on certain third countries, 20 June 1994, OJ (1996) C 274, pp. 52-5.

${ }^{351}$ In a recent case, the ECJ considered a Council decision not to allow public access to certain CIREA documents as unlawful. ECJ, Case T-188/98, Kuijer v Council of the European Union, Published April 14, 2000.

352 This is said to violate the principle of 'equality in arms' in determination procedures. European Parliament, 1997, p. 24. Calls in a European Parliament Resolution to make the work of CIREA more transparent, and to admit non-governmental information to its dissemination system have remained unheard. European Parliament, Resolution on the harmonization within the European Communities of asylum law and policies, A30337/92, para. 33. 


\section{CHAPTER 4}

satisfactory. ${ }^{353}$ At best, this may imply that they exercise caution in using such data for decision-making. Nonetheless, as data collected through CIREA is disseminated among domestic authorities, the risk prevails that individual bureaucrats also use them, regardless of doubts at the ministerial level.

\subsubsection{Maastricht-Progress through Split Competencies?}

Comparing the normative output of the Schengen co-operation with that of the European Political Co-operation at the beginning of the nineties would make it perfectly clear that the EPC simply lagged behind. The EPC had only accomplished 22 binding norms enshrined in the Dublin Convention, while the Schengen Group had produced 142 articles on a broad variety of migration-related topics in the Schengen Convention alone. Within the Schengen Group, the abolishment of border controls was no longer unrealistic. Within the EC at large, it certainly was.

The delegations to the 1991-2 Inter-governmental conference (henceforth IGC) preparing the Treaty of Maastricht were well aware of the limited output of the EPC. The integration process simply needed a tighter structure and a proper institutional framework. What could be accomplished in Maastricht were first steps in that direction: a partial EC competence was created for visa issues, and the brunt of remaining questions were to be handled by the newly-created Union framework. Hence, Maastricht split competencies into a supranational piece under the first pillar and an intergovernmental chunk under the third pillar. This made the geometry of integration more complex. To the separation of Member States into the Schengen avant-garde and a group of backbenching governments, Maastricht would add a separation of asylum and migration issues into EC law and Union law.

353 According to a 1998 draft strategy paper by the Austrian Presidency, 'data on overall figures (i.e. for instance, number of asylum seekers or illegal border-crossers apprehended in a particular year)' are missing in spite of joint collection exercises. Council of the European Union, Note from the Presidency to the K.4 Committee, Strategy paper on migration and asylum, 1 July 1998, Doc. No. 9809/98, para. 74. It must be considered a serious shortcoming, if basic data on the number of yearly applications at borders are missing. One may wonder how the Council is to make joint assessment of persecutory risks in third countries, if it is incapable of sorting out what happens at the frontiers of Member States. 
The Union competence was laid down and specified in Title VI of the TEU. Under Article K.1, Member States agreed to consider the following items as issues of common interest: (1) asylum policies; (2) rules on the passage of persons of the external borders of Member States, and the exercise of control thereon; (3) immigration policy and policies towards third country nationals as regards their entry and movement, conditions for their residence on the territories of Member States, including family reunification and access to employment, and combating illegal immigration. Precisely as was the case for the whole of the third pillar, these issues would be subject to unanimous decision-making by the Council. According to Article K.3 TEU/Maastricht, relevant measures could be given the form of joint positions, joint actions and conventions. Only the latter offered undisputed force to bind Member States in a legal sense. ${ }^{354}$ To be sure, the ECJ has no competence to rule on measures adopted under the third pillar. ${ }^{355}$ However, supranationalism was not completely banned from the third pillar: a two-thirds majority was sufficient to decide on measures for carrying out a joint action or a convention. ${ }^{356}$

The Community competence was enshrined in Article 100c TEC, empowering the Community to adopt a list of third countries whose nationals must be in possession of visas when crossing the external borders of the Member States. To wit, the transgression to supranationalism was softened by paragraph (3) of the said provision: until 1 January 1996, unanimity was required in the Council, but from that date on, a decision could be taken by qualified majority. In exercising this competence, the EC could make use of all instruments offered by community law, including those having binding force.

By means of the passerelle in Article $\mathrm{K} .9 \mathrm{TEU}^{357}$, measures concerning asylum and immigration could have been moved over to Community competence. The procedure was somewhat less demanding than a treaty

\footnotetext{
354 See chapter 1.4.2.6 above on the legal effects of joint actions and joint positions.

355 Nonetheless, the Commission may, of course, challenge any third pillar measures infringing EC competence. Moreover, a convention concluded under Art. K.3 (c) TEU/Maastricht may give competence to the ECJ on matters of interpretation and application. As no conventions were concluded under that provision, the ECJ never received that competence.

356 Art. K.3 (2) (b) and (c) TEU/Maastricht.

357 The french term passerelle (footbridge) is widely used as a metaphor for this norm.
} 


\section{CHAPTER 4}

amendment, but required the unanimous decision of the Council and acceptance by national constituencies. The passerelle was never used. Instead, the Amsterdam Treaty provided for a gradual shift of asylum and immigration issues to a supranational level.

Until the Amsterdam Treaty entered into force and ended the Maastricht era in 1999, two visa-related instruments were adopted under the first pillar. As they were given the form of regulations, they had binding force. The third pillar did not yield a single convention under the same period. It brought about a number of non-binding texts, of which the majority was given the form of atypical instruments. ${ }^{358}$ Therefore, it comes as no surprise that the Maastricht acquis was criticized for its inefficiency. ${ }^{359}$

What issues dominated the Maastricht era? In the three areas of asylum, external border control and migration, the latter clearly dominated by the sheer number of adopted instruments, most of which relate to the topics of readmission and return. By virtue of the two visa regulations, the external border issue stands out as the only one that features binding instruments. In the asylum area, two instruments merit special mention, as they directly allude to the legal classification and the standing of individual protection seekers: the 1995 Resolution on Minimum Guarantees in Asylum Procedures and the 1996 Joint Action on the Harmonized Application of the Refugee Definition. Another noteworthy attempt to solve a central problem of harmonized protection was the adoption of a resolution on burden-sharing of displaced persons in 1995. The remaining instruments of the asylum acquis refined information collection procedures or provided for the monitoring of adopted instruments.

358 In the asylum acquis, there is only one Joint Position, which is expressly deprived from any binding force in the domestic domain. Eleven atypical instruments were adopted in the asylum area (of which three stem from the EPC era). In the migration acquis, we find two Joint Actions, and, apart from the named two EC regulations, the astonishing number of 26 atypical instruments (of which one stems from the EPC era). The acquis on external borders features two joint actions, one joint position, two EC regulations and one atypical instrument. In the training area, four joint actions were adopted, of which one related to asylum. See Draft List and Draft List Addendum.

359 See further R. Bank, 'The Emergent EU Policy on Asylum and Refugees. The New Framework Set by the Treaty of Amsterdam: Landmark or Standstill?’, 68 NJIL 1 (1999), p. 8. 
Among sceptics of the integration process, a recurrent theme in the critical assessment of the Maastricht era was the lack of transparency in decision-making ${ }^{360}$ and the absence of judicial scrutiny of adopted instruments. ${ }^{361}$ As we shall see below, cautious steps towards greater openness and accountability have been taken since the Maastricht period. However, in spite of their questionable democratic merits, the instruments adopted in that period are still applicable today and play an important role in the enlargement process.

\subsubsection{Planning the Economy of Harmonization: Amsterdam}

A major reshuffle of competencies, a binding time-table for future integration, the integration of the Schengen acquis and a protocol slashing the standing of protection seekers who happen to be Union citizensthese were the key achievements of the Amsterdam IGC. The Treaty of Amsterdam entered into force on 1 May 1999 and presently governs the multilateral co-operation on asylum and immigration in the Union. In the following sub-sections, we shall look into the bundle of competencies and obligations spawned by Amsterdam as well as the geometry of integration under it. Together with the Amsterdam Treaty, a 'Protocol on asylum for nationals of Member States of the European Union' was adopted. ${ }^{362}$ This instrument-the so-called Spanish Protocol-shall be dealt with contextually in a later chapter. ${ }^{363}$

360 For an elaborate argumentation, see Curtin and Meijers, 1997, pp. 29-42, suggesting that European integration implies a 'reduction of the democratic content of European society' (at p. 42)

361 The role of the ECJ under the third pillar was a peripheral one. To wit, it had no competencies with regard to the instruments adopted in the asylum and migration area. For an overview, see C. A. Groenendijk, 'The European Court of Justice and the Third Pillar', in B. G. Tahzib, C. A. Groenendijk, M. Vreugdenhill-Klap and J. M. van de Put (eds), Democracy, Migrants and Police in the European Union: The 1996 IGC and Beyond (1997, FORUM, Utrecht).

362 Protocol on Asylum for Nationals of Member States of the European Union, annexed to the Treaty on European Union and to the Treaty establishing the European Community, 6 October 1997, Doc. No. CONF 4007/97, TA/P/en 24 [hereinafter Spanish Protocol].

363 See section 6.2 below. 


\section{CHAPTER 4}

\subsubsection{Competencies and Obligations}

At first sight, the most striking change brought about by the Amsterdam Treaty is a wholesale transfer of asylum and immigration matters from the third to the first pillar. Although a corset of intergovernmental elements in decision-making has significantly reduced the impact of this transfer, new doors have been opened. The move to the first pillar makes the powerful legislative tools of Article 251 TEC available (that is, regulations, directives and decisions), offering undisputed bindingness, justiciability and, under certain preconditions, even direct effect. Henceforth, the Council may adopt regulations, directives and decisions in a wide array of specified issues relating to asylum, external borders and immigration, and not only in certain visa issues. Furthermore, scrutiny of adopted measures now comes under the ambit of the ECJ.

Technically, this has been achieved by inserting a new Title IV into the TEC. The portal provision of this title, Article 61, delimits the competencies of the Community under this title:

In order to establish progressively an area of freedom, security and justice, the Council shall adopt:

(a) within a period of five years after the entry into force of the Treaty of Amsterdam, measures aimed at ensuring the free movement of persons in accordance with Article 14, in conjunction with directly related flanking measures with respect to external border controls, asylum and immigration, in accordance with the provisions of Article 62(2) and (3) and Article 63(1)(a) and (2)(a), and measures to prevent and combat crime in accordance with the provisions of Article 31(e) of the Treaty on European Union;

(b) other measures in the fields of asylum, immigration and safeguarding the rights of nationals of third countries, in accordance with the provisions of Article 63; [...]

The main ideas of the whole title are spelt out here. With the allusion to 'an area of freedom, security and justice', a new telos is introduced or, rather, the 'abolishment of internal border controls' is cloaked in less technocratic apparel. The provision also couples free movement measures to 'flanking measures'. Here, freedom through control-a paradigm running through the history of integration since the mid-eightiesresurfaces. However, the competencies meted out in the provision come with obligations. The Council is assigned to adopt both categories of 
measures within five years after the entry into force of the Amsterdam Treaty. This transitory period will end on 1 May 2004. The inclusion of a time-table makes the Amsterdam approach fundamentally different from the one taken in Maastricht: integration is sought not merely by enhancing competencies, but by setting out a binding schedule of achievements and by phasing in supranational decision-making corresponding to this time-table. Title IV suggests that the internal market needs a dose of planned economy.

However, the Community competencies under Title IV are neither allembracing nor exclusive. ${ }^{364}$ Articles 62 and 63 TEC enumerate the issues within EC competence in an exhaustive manner. Thus, there is no comprehensive EC competence in the areas of visa, asylum, immigration and external borders. Those issues not specified in Articles 62 and 63 TEC remain within the competence of the Member States. The enumerative approach is markedly different from the sweeping competencies meted out in the third pillar by the Maastricht Treaty. Moreover, as long as the Community has not made use of its competence, Member States remain free to legislate. The competence of Member States is also retained in areas where the Community has adopted measures setting out minimum standards, as long as domestic legislation accommodates those standards. ${ }^{365}$ Finally, Article 64 TEC prescribes that Title IV 'shall not affect the exercise of the responsibilities incumbent upon Member States with regard to the maintenance of law and order and the safeguarding of internal security'. ${ }^{366}$

${ }^{364}$ K. Hailbronner, 'Die Neuregelung der Bereiche Freier Personenverkehr, Asylrecht und Einwanderung', in W. Hummer (ed.), Die Europäische Union nach dem Vertrag von Amsterdam (1998, Manz, Vienna), p. 180.

365 Art. 63 TEC specifies this repartition of competencies further. Measures on immigration policy and measures defining the rights and conditions under which nationals of third countries which are legally resident in one Member State may reside in other Member States do not prevent any Member State from maintaining or introducing national provisions which are compatible with the TEC and with international agreements.

366 For an argument that Art. 64 (1) TEC does not prejudice the powers of the ECJ under Title IV, see G. Noll and J. Vedsted-Hansen, 'Non-Communitarians: Refugee and Asylum Policies', in P. Alston (ed.), The European Union and Human Rights (1999, OUP, Oxford), p. 374. 


\section{CHAPTER 4}

Which issues does the enumeration embrace? The Council is assigned to adopt the following measures within a period of five years after the entry into force of the Treaty of Amsterdam:

- measures on the crossing of internal borders ${ }^{367}$;

O measures on the crossing of the external borders of the Member States, establishing standards and procedures to be followed by Member States in carrying out checks on persons at such borders ${ }^{368}$ as well as rules on visas for intended stays of no more than three months ${ }^{369}$;

- measures setting out the conditions under which nationals of third countries shall have the freedom to travel within the territory of the Member States during a period of no more than three months $s^{370}$;

- criteria and mechanisms for determining which Member State is responsible for considering an application for asylum submitted by a national of a third country in one of the Member States ${ }^{371}$;

- minimum standards on the reception of asylum seekers in Member States ${ }^{372}$

- minimum standards with respect to the qualification of nationals of third countries as refugees ${ }^{373}$;

- minimum standards on procedures in Member States for granting or withdrawing refugee status ${ }^{374}$;

- minimum standards for giving temporary protection to displaced persons from third countries who cannot return to their country of origin and for persons who otherwise need international protection ${ }^{375}$; and

\footnotetext{
367 Art. 62 (1) TEC.

${ }^{368}$ Art. 62 (2) (a) TEC.

369 Art. 62 (2) (b) TEC.

370 Art. 62 (3) TEC.

371 Art. 63 (1) (a) TEC.

372 Art. 63 (1) (b) TEC.

${ }^{373}$ Art. 63 (1) (c) TEC.

${ }^{374}$ Art. 63 (1) (d) TEC.

${ }^{375}$ Art. 63 (2) (a) TEC.
} 
- measures on illegal immigration and illegal residence, including repatriation of illegal residents. ${ }^{376}$

For the sake of simplicity, we may call these measures 'the obligatory measures' in the following.

The temporal obligation is not merely a political one, but possesses legal character. If the Council fails to act, the Member States and the other institutions of the Community may bring an action before the Court of Justice under Article 232 TEC. ${ }^{377}$ However, the drafters could not agree to affix temporal obligations to all of the issues enumerated under Title IV. Strikingly, Article 63 TEC exempts three types of measures from the obligation to legislate within five years:

O measures promoting a balance of effort between Member States in receiving and bearing the consequences of receiving refugees and displaced persons (burden-sharing) ${ }^{378}$;

- measures on the conditions of entry and residence, and standards on procedures for the issue by Member States of long term visas and residence permits, including those for the purpose of family reunion (legal immigration) ${ }^{379}$; and

o measures defining the rights and conditions under which nationals of third countries who are legally resident in a Member State may reside in other Member States (mobility rights for legally present aliens). ${ }^{380}$

In doing so, the drafters created a hierarchy within the competencies of Article 63 TEC, dividing measures into an obligatory and a facultative group. To be sure, measures adopted earlier set the parameters for those adopted later. The consequences of the exemption of burden-sharing from the list of obligatory measures shall be discussed extensively in a specific section of this work. ${ }^{381}$

\footnotetext{
376 Art. 63 (3) (b) TEC.

377 Hailbronner, 1998, p. 182.

378 Art. 63 (2) (b) TEC.

379 Art. 63 (3) (a) TEC.

380 Art. 63 (4) TEC.

381 See chapter 8.3 .3 below.
} 


\section{CHAPTER 4}

\subsubsection{Decision Making under Title IV}

How shall the Community exercise the competencies enumerated in Articles 62 and 63 TEC? Torn between demands of increased supranationality and the insistence of certain Member States on veto power, the Amsterdam drafters resorted to piecemeal engineering. To start with, the hopes and expectations of supranationalists were thwarted: the move to the first pillar did not imply automatic access to majority vote. Rather, Title IV relies on the gradual phasing in of supranational decision making.

Title IV offers two distinct decision-making procedures. One turns on unanimity voting in the Council and is applicable to most of the measures enumerated in Articles 62 and 63 TEC. The other is based on a vote by qualified majority in the Council and applies to certain measures on visas.

The unanimity procedure comes in two varieties-one applicable before 1 May 2004 and another thereafter. Before 1 May 2004, the procedure envisages that the Council take a unanimous decision on proposals from the Commission or on initiative by a Member State and after consultation of the European Parliament. ${ }^{382}$ One should note the overlapping time-frames: this predominantly intergovernmental procedure will be applied to the original adoption of the obligatory measures under the five-year period. Thus, the Member States have secured for themselves a strong position for determining the content of the first cohort of Community acts. This is no different from the intergovernmental procedure under the third pillar of the Maastricht era.

After 1 May 2004, and without any further decision, the Commission acquires a monopoly right of initiative. From that date on, the Council shall act on proposals from the Commission, and the Commission shall examine any request made by a Member State that it submit a proposal to the Council ${ }^{383}$ Still, under both varieties of the unanimity procedure, the European Parliament has no power to amend or to veto a text.

Continuing the tradition inaugurated by Article K.9 TEU/Maastricht, Title IV also features a new passerelle. Article 67 (2) TEC provides for an optional transition to the co-decision procedure after 1 May 2004: '[T] Council, acting unanimously after consulting the European Parliament, shall take a decision with a view to providing for all or parts of the areas

\footnotetext{
382 Art. 67 (1) TEC.

383 Art. 67 (2) TEC.
} 
covered by this Title to be governed by the procedure referred to in Article 251 and adapting the provisions relating to the powers of the Court of Justice'. This provision opens an avenue towards expanded supranationalism, but it remains a non-binding offer. Although it uses the verb 'shall', there is no time set out-or, for that matter, implied-for the accomplishment of this obligation. ${ }^{384}$ Hence, should the Council remain passive, it would be hard to argue an infringement of this obligation under Article 232 TEC. In practice, if the Council does not wish to introduce a transition to the co-decision procedure, it simply refrains from taking that decision. This would imply that unanimity voting would continue to dominate this area. ${ }^{385}$ Should the Council decide to make use of the transitory offer, it remains free to choose which issues to transfer; after all, the transitory decision may refer to 'all or parts of the areas' covered by Title IV.

The qualified majority procedure applies to certain measures regulating visas for intended stays of no more than three months. One group of norms is immediately placed under the qualified majority procedure, while another group shall be transferred to it on 1 May 2004. First, for those issues which had been located in the first pillar already during the Maastricht era, the situation remains unchanged: such measures are adopted by the Council acting by a qualified majority on a proposal from the Commission and then consulting the European Parliament. ${ }^{386}$ This procedure applies to the adoption of a list of third countries whose nationals must be in possession of visas when crossing the external borders (the so-called negative list) ${ }^{387}$ and of a uniform format for visas. ${ }^{388}$ To those issues, the Treaty of Amsterdam added another, namely the

384 This assessment is not altered by the non-binding Declaration on Article 730 of the Treaty establishing the European Community (Declaration No. 21 annexed to the Final Act of the Inter-Governmental Conference): 'The Conference agrees that the Council will examine the elements of the decision referred to in Article $730(2)$, second indent, of the Treaty establishing the European Community before the end of the five year period referred to in article 730 with a view to taking and applying this decision immediately after the end of that period.' In the course of consolidation of the Treaties, Art. 73o was renumbered to Article 67.

385 For an elaborated argument to this effect, see A. Weber, 'Möglichkeiten und Grenzen europäischer Asylrechtsharmonisierung vor und nach Amsterdam', 18 ZAR 4 (1998), p. 148.

386 Art. 67 (3) TEC.

387 Art. 62 (2) (b) (i) TEC.

388 Art. 62 (2) (b) (iii) TEC. 


\section{CHAPTER 4}

adoption of a list of third countries whose nationals are exempt from a visa requirement when crossing external borders (the so-called positive list). ${ }^{389}$

Second, two further visa issues are maintained under the unanimity procedure until 1 May 2004, to be automatically transferred to the qualified majority procedure under Article 251 TEC afterwards. Those issues cover measures on the procedures and conditions for issuing visas by Member States and on rules on a uniform visa. ${ }^{390}$

Taking a birds-eye view on Title IV, it is fair to say that the veto principle still dominates this regulatory area. In effect, the solution chosen in Article 67 TEC is structurally identical to the old 'passerelle' in Article K.7 TEU/Maastricht and the question imposes itself, whether any substantial progress has been attained. During the Amsterdam IGC, neither Germany nor the U.K. were willing to cede the unanimity trump in numerous areas. ${ }^{391}$ Thus, the gains for supranationalism consisted of partial advances. The price to be paid for them was a confusing multitude of decision-making procedures.

\subsubsection{The Role of the ECJ}

The Amsterdam Treaty has given the ECJ competence of interpretation in the areas circumscribed in Title IV TEC. This must be counted among the most important supranationalist onslaughts in the field. It opens measures on asylum, external borders and immigration to judicial review, and it provides for the resolution of interpretatory conflicts, both on the supranational and the national level. In principle, the ECJ may be seized and act through the procedures laid down for it in the $\mathrm{TEC}^{392}$, with two important modifications, of which one is relevant in the present

\footnotetext{
${ }^{389}$ Art. 62 (2) (b) (i) TEC.

390 Art. 67 (4) TEC compared to Art. 62 (2) (b) (ii) and (iv) TEC.

391 Hailbronner, 1998, p. 191.

392 The relevant norms can be found in Part Five, Title I, Chapter 1, Section 4 TEC.
} 
context. ${ }^{393}$ The threshold for seizing the ECJ for purposes of interpretation has been elevated. Article 68 (1) TEC expounds when a referral to the ECJ shall take place:

Article 234 shall apply to this Title under the following circumstances and conditions: where a question on the interpretation of this Title or on the validity or interpretation of acts of the institutions of the Community based on this Title is raised in a case pending before a court or a tribunal of a Member State against whose decisions there is no judicial remedy under national law, that court or tribunal shall, if it considers that a decision on the question is necessary to enable it to give judgment, request the Court of Justice to give a ruling thereon.

The difference with respect to the standard procedure under Article 234 TEC is obvious. Not any court, but only such courts, against whose decisions there is no judicial remedy in the domestic system, may refer a question to the ECJ. In contrast to the procedure under Article 234 TEC, that Court is not under an unqualified obligation to make a referral, but shall do so 'if it considers that a decision on the question is necessary to enable it to give judgment'. This opens a margin of discretion to the relevant domestic court, tempting some commentators to conclude that referral as such is facultative. ${ }^{394}$ As Gialdino has pointed out, such an interpretation would, inter alia, run counter to the wording and context of the very provision. ${ }^{395}$ After all, the drafters opted for the term 'shall' and against inclusion of the phrase 'may request', which was used when regulating the competence of the ECJ in Article 35 (3) TEU. Therefore, the margin of appreciation under Article 68 (1) TEC is limited: where a relevant court has established that it is confronted with a question of

${ }^{393}$ Following Art. 68 (2) TEC, the ECJ does not have jurisdiction to rule on any measure or decision on the crossing of internal borders under Art. 62 (1) TEC relating to the maintenance of law and order and the safeguarding of internal security. This exception is of no further importance for the areas of asylum, external borders and immigration. Accord: Bank, 1999, p. 25, Noll and Vedsted-Hansen, 1999, p. 374. See also Hailbronner, 1998, p. 192.

${ }^{394}$ For an account of such positions, see C. C. Gialdino, 'Schengen et le troisième pilier: le contrôle juridictionnel organisé par le traité d'Amsterdam', 1998 Revue du Marché Unique Européen 2 (1998), pp.105-6.

395 See Gialdino, 1998, pp. 106-7, adducing further arguments for an obligatory referral. 


\section{CHAPTER 4}

interpretation under Article 68 (1) TEC, it is under an obligation to refer the case to the ECJ. ${ }^{396}$

An innovation for the whole area of EC law is the competence of the ECJ to give advisory rulings on interpretative questions under Title IV. According to Article 68 (3) TEC,

[t]he Council, the Commission or a Member State may request the Court of Justice to give a ruling on a question of interpretation of this Title or of acts of the institutions of the Community based on this Title. The ruling given by the Court of Justice in response to such a request shall not apply to judgments of courts or tribunals of the Member States which have become res judicata.

Together with the ECJ competence in contentious cases, this mechanism could very well contribute to a more harmonious interpretation of Title IV and the measures conceived under it. However, the limitative moments built into judicial control must be seen against the background of the substantially augmented competencies of the EC and the availability of binding instruments under Article 249 TEC. This accumulated empowerment is not matched by an equivalent empowerment for the ECJ. Therefore, in the grand total, Title IV amounts to a weakening of the individual's legal standing. ${ }^{397}$

After the transitory period of five years, the Council may adapt the rules on the competence of the ECJ. As earlier mentioned, Article 67 (2) TEC states that

the Council, acting unanimously after consulting the European Parliament, shall take a decision with a view to providing for all or parts of the areas covered by this Title to be governed by the procedure referred to in Article 251 and adapting the provisions relating to the powers of the Court of Justice.

Thus, provided that the Council decides to move all or parts of the relevant areas over to the co-decision procedure after the transitory period, this decision must also provide for a congruent adaptation of the ECJ competencies. However, the quoted provision does not prescribe the precise nature or extent of such an adaptation.

\footnotetext{
396 Gialdino, 1998, p. 106.

397 Accord: Gialdino, 1998, p. 104; see also Noll and Vedsted-Hansen, 1999, p. 373.
} 


\subsubsection{The Position of Denmark, Ireland and the U.K.}

In the course of the Amsterdam negotiations, Denmark, Ireland and the U.K. were not prepared to accept a further communitarization in the area of asylum, external borders and immigration. ${ }^{398}$ However, none of these countries opposed movement of these issues to the first pillar by the remaining twelve Member States, provided that the rights and obligations of the three outsiders remained untouched by such a move. Thus, the communitarization described earlier has been achieved not for all Member States, but only among twelve of them, creating a 'variable geometry' of integration. The practical arrangements have been laid down in the Protocol on the Position of the United Kingdom and Ireland ${ }^{399}$ and in the Protocol on the Position of Denmark. ${ }^{400}$ Principally, all three sceptics are not participating in the adoption of instruments under Title IV TEC. ${ }^{401}$ Therefore, adopted measures or interpretative decisions of the ECJ in this area are not binding, applicable, or otherwise entitling or obliging upon the three states. ${ }^{402}$ Protocol No. 4 lays down an opt-in mechanism for Ireland and the U.K., allowing each of these states, or both, to participate in the elaboration, adoption and application of measures under Title IV TEC. ${ }^{403}$ Such a mechanism does not exist for Denmark. ${ }^{404}$

Thus, on issues relating to Title IV TEC, the Member States are not a homogeneous group. This has consequences. First, it entails detailed rules

${ }^{398}$ However, Denmark has to co-operate on those visa issues already within EC competence in the Maastricht era (measures determining the third countries whose nationals must be in possession of a visa when crossing the external borders of the Member States and measures relating to a uniform format for visas). Prot. 7, Art. 4.

399 Protocol on the Position of the United Kingdom and Ireland; annexed to the Treaty on European Union and to the Treaty establishing the European Community, 6 October 1997, Doc. No. CONF 4007/97, TA/P/en 15 [hereinafter Irish-British Protocol].

400 Protocol on the Position of Denmark, annexed to the Treaty on European Union and to the Treaty establishing the European Community, 6 October 1997, Doc. No. CONF 4007/97, TA/P/en 19 [hereinafter Danish Protocol].

401 Irish-British Protocol, Art. 1, Danish Protocol, Art. 1.

${ }^{402}$ Irish-British Protocol, Art. 2, Danish Protocol, Art. 2.

${ }^{403}$ Irish-British Protocol, Art. 3 (1).

${ }^{404}$ However, Art. 7 of the Danish Protocol provides for a comprehensive opt-in to cooperation within Title IV: 'At any time Denmark may, in accordance with its constitutional requirements, inform the other Member States that it no longer wishes to avail itself of all or part of this Protocol. In that event, Denmark will apply in full all relevant measures then in force taken within the framework of the European Union.' 


\section{CHAPTER 4}

on the weighing of voices in the Council and on the financing of measures and their administration. ${ }^{405}$ Second, for each measure adopted under Title IV TEC, the geographical scope of application must be established individually, taking into account any opt-in by the three outsiders.

\subsubsection{The Integration of the Schengen acquis}

Bringing the Schengen avant-garde back into the Union mainstream was one of the more ambitious aspirations of the Amsterdam IGC. The task was not an easy one, and entailed an extraordinarily complex normative apparatus, involving both the third and the first pillar, and catering for the specific situation of Denmark, Ireland and the U.K. With Iceland and Norway, two countries outside the Union had to be involved to secure the viability of the Nordic Passport Union. There is no need to include an exhaustive presentation of this integrative effort here ${ }^{406}-i$ it sufficient to examine those issues having a bearing on asylum and immigration issues.

The integration of the Schengen acquis is provided for in the Schengen Protocol ${ }^{407}$ attached to the treaty of Amsterdam, to be regarded as an integral part of it, and binding under international law. Simultaneously with the entry into force of the Amsterdam Treaty, the Schengen acquis has become applicable among the Thirteen, and the Council has substituted itself for the Schengen Executive Committee. ${ }^{408}$

The Schengen acquis consists of the following norms:

O The Schengen Agreement;

O The Schengen Convention, with related Final Act and common declarations;

O The Accession Protocols and Agreements to the 1985 Agreement and the 1990 Implementation Convention with Italy, Spain,

${ }^{405}$ For a detailed presentation, see K. Hailbronner and C. Thiery, 'Der neue Titel im EGV: Freier Personenverkehr, Asylrecht und Einwanderung', 1998 EuR 5 (1998), pp. 597-602.

406 See J. de Zwaan, 'Opting Out and Opting In: Problems and Practical Arrangements under the Schengen Agreement', 1 The Cambridge Yearbook of European Legal Studies (1998).

407 See note 326 above.

${ }^{408}$ Schengen Protocol, Art. 2 (1). 
Portugal, Greece, Austria, Denmark, Finland and Sweden with related Final Acts and declarations; and

- Decisions and declarations adopted by the Schengen Executive Committee, as well as acts adopted for the implementation of the Convention by the organs upon which the Executive Committee has conferred decision making powers.

The Council, acting unanimously, shall determine, in conformity with the relevant provisions of the Treaties, the legal basis for each of the provisions or decisions that constitute the Schengen acquis. ${ }^{409}$ As the norms pertaining to the Schengen acquis stretch over a broad array of issues, there are two choices. Either such provisions or decisions can be based on Title IV TEC or, failing that, on the third pillar. Norms allocated to the first pillar are EC law, while those allocated to the third pillar are norms of international law. ${ }^{410}$ So far, a number of Schengen instruments have been transposed. ${ }^{411}$

The allocation of Schengen norms among the first and third pillar also impacts the role of the ECJ. The Schengen Protocol states: 'With regard to such provisions and decisions and in accordance with that determination, the Court of Justice of the European Communities shall exercise the powers conferred upon it by the relevant applicable provisions of the Treaties'. ${ }^{412}$

It merits recalling that the competencies of the ECJ are much broader under the first pillar (Article 68 TEC) than they are under the third (Article 35 TEU). In any event, the Schengen Protocol states that the ECJ shall have no jurisdiction on measures or decisions relating to the maintenance of law and order and the safeguarding of internal security. ${ }^{413}$ This exception is much broader than the one introduced in Article 68 (2) TEC, as the latter solely encompasses measures relating to the abolishment of checks at internal borders. This means that the judicial

409 Schengen Protocol, Art. 2 (1). This provision also prescribes that, as long as the measures referred to above have not been taken, the provisions or decisions that constitute the Schengen acquis shall be regarded as acts based on Title VI TEU. On the exact delimitation of the Schengen acquis, see Hailbronner and Thiery, 1998, pp. 607-8.

${ }^{410}$ Hailbronner and Thiery, 1998, p. 608.

${ }^{411}$ See OJ (1999) L 119/49, L 176/1, L176/17, L 176/31, L 176/34, L 176/35.

${ }^{412}$ Schengen Protocol, Art. 2 (1).

${ }^{413}$ Schengen Protocol, Art. 2 (1). 


\section{CHAPTER 4}

control of Schengen norms allocated to the first pillar is less dense than that of other norms under the same pillar.

Beyond the mere qualification of the existing Schengen acquis, the institutions are competent to adopt further measures within its scope. Such elaboration is faced with the same choice, depending on the subject matter; relevant measures shall be adopted either under the first or the third pillar. ${ }^{414}$ To be sure, the aforementioned limitation of the Court's competence with regard to law and order as well as internal security ${ }^{415}$ does not apply to such norms.

\subsubsection{The Variable Geometry of Integration}

At this stage, a rather complex picture of co-operation has emerged, stretching over the first and the third pillar as well as over international law beyond the institutional framework of the Union. Before we proceed, it should be sufficient to briefly reiterate which regime applies to each single country involved in the co-operation. To facilitate comparison, the most essential features of the regime are presented in Table 1.

For the Schengen Group, the situation is relatively simple. With the exception of Denmark, all Schengen states will participate in the cooperation under Title IV TEC without any reservations.

Denmark is not participating in the co-operation under Title IV TEC, save for measures determining the third countries whose nationals must be in possession of a visa when crossing the external borders of the Member States, or measures relating to a uniform format for visas. ${ }^{416}$ Denmark will apply the parts of the Schengen acquis that were adopted before the Treaty of Amsterdam entered into force. However, Denmark is not participating in the further development of the Schengen acquis under Title IV TEC. By means of an opt-in procedure, Denmark can accept to be bound by a measure developing the Schengen acquis. This creates an obligation under international law between Denmark and the

\footnotetext{
414 Schengen Protocol, Art. 5 (1).

415 See text accompanying note 413.

${ }^{416}$ Danish Protocol, Art. 4.
} 
other Schengen countries. ${ }^{417}$ There is no such opt-in procedure for other measures adopted under Title IV TEC. ${ }^{418}$

The United Kingdom does not participate in the co-operation of Member States under Title IV TEC, nor is it member in the Schengen Group. However, the United Kingdom can avail itself of an opt-in procedure, allowing it to accept single measures adopted under Title IV TEC, whether or not they build on the Schengen acquis. It can also accept any of the instruments and decisions contained in the Schengen acquis by the same procedure.

In order to preserve the 'Common 'Travel Area' between both countries, Ireland has decided to take the same position as the United Kingdom. However, Ireland has set a lower threshold for entering cooperation under Title IV TEC. It may notify the President of the Council in writing that it no longer wishes to be covered by the terms of Protocol No. 4. In that case, the normal treaty provisions will apply to Ireland. ${ }^{419}$

To ensure the continued functionality of the Nordic Passport Union and the free movement of persons realized therein, Norway and Iceland have associated themselves with the Schengen co-operation. To that effect, an association agreement was concluded between both countries and the Schengen states on 19 December $1996 .{ }^{420}$ After the integration of the Schengen acquis into the Union framework, a new agreement between the named states, which shall replace the 1996 agreement ${ }^{421}$, was signed in 1999. The rationale of this agreement is to extend the application of

${ }^{417}$ Danish Protocol, Art. 5 (1).

418 But see note 404 above.

419 Irish-British Protocol, Art. 8.

${ }^{420}$ Co-operation Agreement between the Kingdom of Belgium, the French Republic, the Federal Republic of Germany, the Grand Duchy of Luxembourg, the Kingdom of the Netherlands, the Italian Republic, the Kingdom of Spain, the Portuguese Republic, the Hellenic Republic, the Republic of Austria, the Kingdom of Denmark, the Republic of Finland, the Kingdom of Sweden, Contracting Parties to the Schengen Agreement and the Schengen Convention, and the Republic of Iceland and the Kingdom of Norway on the abolition of controls on persons at their common borders, signed in Luxembourg on 19 December 1996.

${ }^{421}$ Agreement concluded by the Council of the European Union and the Republic of Iceland and the Kingdom of Norway concerning the latter's association with the implementation, application and development of the Schengen acquis, signed on 17 May 1999 [hereinafter 1999 Agreement]. 


\section{CHAPTER 4}

norms pertaining to the law of the European Union and related to the abolishment of internal border control to Iceland and Norway:

O The existing Schengen acquis is implemented and applied by Iceland and Norway. ${ }^{422}$

O Certain existing EC acts are implemented and applied by Iceland and Norway, inter alia the Visa Regulation. ${ }^{423}$

O Future acts and measures by the EU amending or building upon the aforementioned norms shall be accepted, implemented and applied by Iceland and Norway. ${ }^{424}$

- An agreement on the criteria and mechanisms for establishing the State responsible for examining a request for asylum lodged in any of the Member States or in Iceland or Norway should be concluded before the existing acquis enters into force in Iceland and Norway. ${ }^{425}$ This agreement would fulfil the same function as is fulfilled by the Dublin Convention among Member States.

The adoption of new acts or measures is explicitly reserved to the competent institutions of the European Union. ${ }^{426}$ Such acts have to be formally accepted by Iceland and Norway, and a specific procedure has been laid down in the agreement. ${ }^{427}$ However, non-acceptance of any of these measures may lead to the wholesale termination of the agreement between the non-accepting party and the other parties. ${ }^{428}$ In other words, the costs of non-acceptance are very high. To mitigate the transfer of sovereign powers effectuated under the agreement, a mixed commission

\footnotetext{
422 Art. 2 (1) 1999 Agreement. The relevant norms are listed in Annex A.

423 Art. 2 (2) 1999 Agreement. The relevant norms are listed in Annex B.

424 Art. 2 (3) 1999 Agreement. This provision covers all norms listed in Annex A and B.

425 Art. 71999 Agreement.

426 Art. 8 (1) 1999 Agreement.

427 Art. 8 (2) 1999 Agreement.

428 Art. 8 (4) 1999 Agreement.
} 
has been established to operate as a consultation body in this cooperation. $^{429}$

Furthermore, as Ireland and the U.K. may opt into all or parts of the Schengen acquis, it has become necessary to regulate the legal relationship of those countries with Norway and Iceland. Based on the Schengen Protocol, a separate agreement has been drawn up, specifying the rights and obligations between the named four countries. ${ }^{430}$

${ }^{429}$ See Art. 3 of the 1999 Agreement. The working procedure of the mixed committee is laid down in Decision No. 1/1999 of the EU/Iceland and Norway Mixed Committee established by the agreement concluded by the Council of the European Union and the Republic of Iceland and the Kingdom of Norway concerning the latter's association in the implementation, application and development of the Schengen acquis of 29 June 1999 adopting its Rules of Procedure, 29 June 1999, OJ (1999) C 211, pp. 9-11.

${ }^{430}$ See Schengen Protocol, Art. 6 (2). The agreement is entitled as follows: Accord conclu entre le Conseil de l'Union Europeenne et la Republique d'Islande et le Royaume de Norvège sur l'etablissement des droits et obligations entre l'Irlande et le Royaume-Uni de Grande-Bretagne et d'Irlande du Nord, d'une part, et la Republique d'Islande et le Royaume de Norvege, d'autre part, dans les domaines de l'acquis de Schengen qui s'appliquent à ces Etats. It is attached to the following Council decision: Decision du Conseil relative à la conclusion de l'accord avec la République d'Islande et le Royaume de Norvège sur l'établissement des droits et obligations entre l'Irlande et le Royaume-Uni de Grande-Bretagne et d'Irlande du Nord, d'une part, et la République d'Islande et le Royaume de Norvège, d'autre part, dans les domaines de l'acquis de Schengen qui s'appliquent à ces Etats, 25/06/99, Doc. Nos 9551/99 JAI 54, 9357/99 JAI 50. 


\begin{tabular}{|c|c|c|c|c|c|}
\hline & Denmark & Ireland & $\begin{array}{l}\text { United } \\
\text { Kingdom }\end{array}$ & $\begin{array}{l}\text { Other } \\
\text { Member } \\
\text { States }\end{array}$ & $\begin{array}{l}\text { Norway and } \\
\text { Iceland }\end{array}$ \\
\hline $\begin{array}{l}\text { Participating } \\
\text { in the adoption } \\
\text { of measures } \\
\text { under Title IV } \\
\text { TEC }\end{array}$ & No & $\begin{array}{l}\text { No } \\
\text { but opt-in } \\
\text { possible } \\
\text { (Prot.4. } \\
\text { Art.3) }\end{array}$ & $\begin{array}{l}\quad \text { No } \\
\text { but opt-in } \\
\text { possible } \\
\text { (Prot.4. } \\
\text { Art.3) }\end{array}$ & Yes & $\begin{array}{l}\text { No } \\
\text { save for } \\
\text { consul- } \\
\text { tations }\end{array}$ \\
\hline $\begin{array}{l}\text { Applying } \\
\text { measures } \\
\text { under Title IV } \\
\text { TEC }\end{array}$ & $\begin{array}{l}\text { No } \\
\text { exception } \\
\text { of certain } \\
\text { visarrelated } \\
\text { measures }\end{array}$ & \begin{tabular}{l}
\multicolumn{1}{c}{ No } \\
but optin \\
possible \\
(Prot.4, \\
Art.4)
\end{tabular} & $\begin{array}{l}\text { No } \\
\text { but opt-in } \\
\text { possible } \\
\text { (Prot.4, } \\
\text { Art 4) }\end{array}$ & Yes & $\begin{array}{l}\text { No } \\
\text { exception } \\
\text { of five } \\
\text { enumerated } \\
\text { acts }\end{array}$ \\
\hline $\begin{array}{l}\text { Applying } \\
\text { the pre- } \\
\text { Amsterdam } \\
\text { Schengen } \\
\text { acquis }\end{array}$ & Yes & $\begin{array}{l}\text { No } \\
\text { but opt-in } \\
\text { possible } \\
\text { (Schengen } \\
\text { Protocol, } \\
\text { Art. 4) }\end{array}$ & \begin{tabular}{l}
\multicolumn{1}{c}{ No } \\
but opt-in \\
possible \\
(Schengen \\
Protocol, \\
Art. 4)
\end{tabular} & Yes & Yes \\
\hline $\begin{array}{l}\text { Decision- } \\
\text { making } \\
\text { power in the } \\
\text { development } \\
\text { of the Schengen } \\
\text { acquis under } \\
\text { Title IV TEC }\end{array}$ & 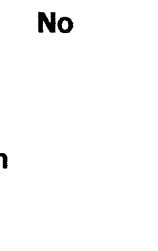 & No & No & Yes & No \\
\hline $\begin{array}{l}\text { Applying } \\
\text { the post: } \\
\text { Amsterdam } \\
\text { Schengen } \\
\text { acquis }\end{array}$ & \begin{tabular}{l}
\multicolumn{1}{c}{ No } \\
but opt-in \\
possible \\
(Prot. 5 , \\
Art. 5)
\end{tabular} & No & No & Yes & $\begin{array}{l}\text { Upon } \\
\text { acceptance } \\
\text { of each new } \\
\text { measure }\end{array}$ \\
\hline
\end{tabular}

Table 1: The variable geometry of integration under Title IV TEC and within the Schengen co-operation 


\subsubsection{Enlarging the Union}

On 30 March 1998, formal negotiations on accession were opened with the thirteen states applying for membership in the European Union. Of these, Cyprus, the Czech Republic, Estonia, Hungary, Poland and Slovenia are considered to possess the best prospects for early membership. As the accession process is most advanced with respect to these states, it is reasonable to touch upon their position under the acquis communautaire and under the international law relating to extraterritorial protection in the course of this work. ${ }^{431}$

The enlargement of the European Union results in a shift of the Union's external borders. Given that intra-Union freedom of movement is one of the central features of the single market, this shift needs to be managed carefully if Member States wish to avoid losing their capacity to control migration. But enlargement is not solely about border control, it is also about the extension of protection capacities to candidate countries. The advantages are obvious. At best, enlargement may imply a form of burden-sharing for Member States, and lead to an expeditious improvement of extraterritorial protection available in candidate countries. Yet the risks are equally obvious. The accession process may also degenerate to burden-shifting eastwards and the export of protection standards could 'replicate EU failings' ${ }^{432}$ or remain a dead letter.

Therefore, it must be deemed reasonable that the adaptation of domestic migration and asylum policies in the candidate countries has been accorded an important role in the pre-accession phase. ${ }^{433}$ Exporting

${ }^{431}$ In Parts III and IV of this work, the named first wave candidate countries will be included into the scope of presentation.

${ }^{432}$ ECRE, ECRE Position on the Enlargement of the European Union in Relation to Asylum, September 1998, Conclusions and Recommendations, para. 3.

${ }^{433}$ For an excellent analysis of the gains and risks of enlargement in the area of asylum, see R. Byrne, 'Future Perspectives: Accession and Asylum in an Expanded European Union', in R. Byrne, G. Noll, and J. Vedsted-Hansen, New Asylum Countries? Migration Control and Refugee Protection in an Enlarged European Union (2000), whose main point is that the deficiencies of the acquis will be amplified when implemented by candidate countries, and that the experience of protection in the East should inspire the reformulation of refugee policy in the West. For a political science perspective, see S. Lavenex, Safe third countries. Extending EU asylum and immigration policies to Central and Eastern Europe (1999, Central European University Press, Budapest). For a brief overview, based mainly on a statistical analysis, see IOM/ICMPD, Migration in Central and Eastern Europe: 1999 Review (1999, IOM, Geneva). See also UNHCR, $3^{\text {td }}$ International Symposium on the 


\section{CHAPTER 4}

the acquis related to protection is not unproblematic, though. After all, from the perspective of the candidate countries, the accession process is about being integrated and not necessarily about integrating 'the other'. In other words, the prime goal of the candidate countries is to receive membership, rather than to extend membership.

The criteria adopted by the 1993 European Council meeting in Copenhagen ${ }^{434}$ constitute the basis for the accession process. These criteria reflect the tension between universal goods and particular interests underlying enlargement. On the universalist side, membership in the Union requires that the candidate country has achieved stability of institutions guaranteeing inter alia human rights. ${ }^{435}$ Needless to say, this includes the protection of certain groups of aliens, including refugees. On the particularist side, 'the ability to take on the obligations of membership' is one of the preconditions for accession. ${ }^{436}$ Among these obligations, we find the duty to guard the external border of the Union.

As pointed out by the Council upon the opening of accession negotiations with six of the candidates, membership obligations comprise the acquis as it evolves; future conventions and instruments, as well as the agreed points of instruments still under negotiation, will have to be taken into account. ${ }^{437}$ The candidate countries will have to implement all instruments belonging to the EU acquis according to their legal nature. ${ }^{438}$ The same applies to the Schengen acquis and further measures taken by the institutions within its scope. ${ }^{439}$ In its basic document underlying the

Protection of Refugees in Central Europe, 23-25 th April, Budapest. Report and Proceedings (1997, UNHCR, Geneva); K. Hakola (ed.), Migration and Refugee Policy on the Eastern Border of the European Union (1998, University of Jyväskylä, Jyväskylä) and M. King, 'The Impact of Western European Border Policies on the Control of Refugees in Eastern and Central Europe', in V. Robinson (ed.), Migration and Public Policy (1999, Edward Elgar Publishing Ltd, Cheltenham).

${ }^{434}$ Conclusions of the Presidency (Copenhagen Summit Conclusions) reprinted in H. Bull, European Communities, June 1993, points 1.1-4.1.

435 Ibid.

${ }^{436}$ Ibid.

${ }^{437}$ Draft List, p. 2, para. 4.

438 The Draft List merely states that the various elements of the acquis do not all have the same legal status. The list itself contains no indication as to the extent to which a particular instrument is legally binding. 'This might be dealt with in explaining the "acquis" to the candidate countries during the screening process.' Draft List, p. 5, para. 12.

439 Schengen Protocol, Art. 8. 
Union's enlargement strategy, dubbed Agenda $2000^{440}$, the Commission proposed bringing together the different forms of pre-accession support provided by the Union within a single framework, the Accession Partnerships. At its meeting on 12-13 December 1997, the Luxembourg European Council endorsed the Accession Partnership as a new instrument destined to be the key feature of the enhanced pre-accession strategy. ${ }^{441}$ As a complement to the Accession Partnership, each candidate country has been invited to adopt a National Programme for the Adoption of the acquis.

Since the opening of negotiations, the EU institutions and single Member States have embarked on large-scale monitoring exercises, training programmes and resource transfers eastwards. ${ }^{442}$ By means of a dedicated Joint Action, the Council has established a group of experts, which is tasked with the 'collective evaluation' of progress made with the implementation of the acquis in the area of justice and home affairs. ${ }^{443}$ Moreover, the Luxembourg European Council has assigned the European Commission the task of compiling so-called regular reports analyzing the progress made in the capacity of each candidate country to implement the acquis.

On the ground, the export of the asylum and migration acquis has been largely channelled through the Union-funded PHARE Horizontal Programme, whose aim is to explain the content of the acquis to candidates and to identify gaps in their protection systems. This programme has provided for extensive training and information events, disseminating knowledge of the asylum acquis in the administrations of candidate countries. On the basis of the assessment of each candidate country's capacity to implement the acquis, National Action Plans are

440 European Commission, Agenda 2000: For a stronger and wider Europe, 15 July 1997, $\operatorname{COM}(97) 2000 \mathrm{final} / 1$.

${ }^{441}$ Luxembourg European Council, Presidency Conclusions, 12 December 1997, Doc. No. SN 400/97, paras 14-6.

${ }^{442}$ For an overview of the enlargement process from an institutional perspective, see $\mathrm{O}$. Seiffarth, 'The Enlargement Process and JHA Co-operation', in P. J. van Krieken (ed.), The Asylum Acquis Handbook (2000, T. M. C. Asser Press, The Hague).

${ }^{443}$ Council of the European Union, Joint Action of 29 June 1998 adopted by the Council on the basis of Article K.3 of the Treaty on European Union, establishing a mechanism for collective evaluation of the enactment, application and effective implementation by the applicant countries of the acquis of the European Union in the field of Justice and Home Affairs, OJ (1998) L 191, pp. 8-9. 


\section{CHAPTER 4}

drawn up, along which the candidate countries and international actors proceed in order to fill the remaining gaps. To that end, they may receive assistance through other PHARE programmes.

Taking a step back, two aspects of the accession process are particularly striking. The first is the hardening of soft law in the accession process, the second the selling of an outdated product to the cousins in the East. While the present Member States are far from having implemented the asylum acquis themselves, they demand strict compliance of the queuing nonmembers. ${ }^{444}$ It is something of a paradox that the rules of the club apply first and foremost to outsiders. What is soft law in the West, may very well take on a harder edge in the East, as Union membership is conditional on its implementation. And, while the shortcomings of the acquis have been identified and become the subject of an overhaul within the Union, the very instruments carrying those defects are being exported to candidate countries. ${ }^{445}$

\subsection{Conclusion}

This chapter began by depicting the dynamics of flight to and within Europe, and continued by tracking integration in the field of immigration and asylum law. Now, having sifted through recent crises as well as the major institutional developments on the way from Schengen to Amsterdam, it might be asked whether it makes sense at all to subsume this process under the heading of integration?

${ }^{444}$ The issue is predominantly a political one. The non-compliance of Member States with the non-binding parts of the acquis is regularly documented in monitoring exercises (see e.g. note 608 below). There is no sufficient political leverage to produce greater compliance within the Union. However, this leverage exists with regard to the queuing candidate countries, for which the soft law of the acquis becomes de facto binding through its conditional linkage to future Union membership.

445 'While the accession process is driving the replication of the asylum acquis, the Commission driven reform underway is acknowledging some of the endemic problems in the asylum practices that the European Union has already exported eastward.' Byrne, 2000 , Section II, in fine. It is quite noteworthy that UNHCR is involved in this transfer within the framework of the PHARE Horizontal Programme, given that it has criticized pivotal elements of the acquis. The Office must have considered that the opportunity to influence information transfer outweighs the risks inherent in its implicit endorsement of the acquis. 
Let us recapitulate. The real world layer was dominated by imploding state control in the East. Borders became permeable again-sometimes to a degree with which liberal governments in the West were quite uncomfortable-and power struggles filling the void left by totalitarianism led to large-scale displacement within Europe. Both issues were more than single Member States could manage unilaterally in the long run. Thus, theoretically, the changing reality of flight and displacement offered good reasons for an advance of multilateralism in the institutional world and, consequently, a boost for regional integration.

Did the institutional layer respond to this challenge? Does it really make sense to speak of European integration with regard to asylum and immigration? The scale of possible responses stretches from outright affirmation to prudent scepticism to determined denial.

For those wishing to answer in the affirmative, good arguments are on offer. In little more than a decade, both issues have moved from a fringe position to the centre, from ad-hoc co-operation outside EC institutions to the first pillar of the Union. In an unprecedented expansion, the number of fora seized with matters related to asylum and migration has multiplied throughout the period. The avant-garde project of Schengen, and its ensuing mainstreaming into the Union framework, is probably the best illustration of these integrative dynamics. Both the Schengen and Dublin Conventions boasted their own executive committees, and cooperation involved an increasing number of administrative echelons in the Member States. There is no precedent in Europe or in other regions of the world with regard to the diversity and depth of co-operation on issues related to flight and migration. The importance of the acquis thus elaborated was further boosted through the enlargement process, which de facto exported a whole regime of protective norms to Central and Eastern European candidate countries.

A prudent sceptic would accept such arguments but point to the side effects of this rapid development. True enough, intergovernmental forms of co-operation largely replaced the prevailing atmosphere of unilateralism, and such co-operation was later channelled into a supranational setting by the Amsterdam Treaty. However, a price had to be paid. From the outset, integration was bought by sacrificing transparency, accountability and judicial control, which did not follow the shift to the intergovernmental level. The move to the first pillar has not compensated 


\section{CHAPTER 4}

for these shortfalls, and integration remains stuck with a considerable legitimacy deficit. ${ }^{446}$

Finally, a radical sceptic would find at least two reasons to support a negative response. First, in more than a decade, the normative output in both fields has been limited in substance. As the following chapter will show, few instruments possess the character of hard law. In addition, many non-binding instruments are vaguely phrased or make deference to domestic law. Second, the term 'integration' suggests a movement towards unity. In the area of protection, there is little evidence in favour, and much in disfavour. ${ }^{447}$ Domestic legislation still differs to a great extent, and protection burdens are concentrated rather than shared. In spite of ever more elaborate supranational mechanisms, there are good reasons to believe that unilateralism will retain an important role in the shaping of practice. The persistence of the veto in decision-making under Title IV is probably the most prominent of these reasons.

To elaborate the multifaceted image of integration further, we need to zoom in on the norms developed on the way from Schengen to

446 'As long as the EP is not given a more powerful position in the procedure, its role can hardly be described as "controlling” the legislative process.' Bank, 1999, p. 24. However, Bank acknowledges that the transfer from the third to the first pillar made important parliamentary control mechanisms accessible-such as the right to set up Committees of Inquiry, to examine petitions, and the processing of claims by the Ombudsman. Ibid. See also Noll and Vedsted-Hansen, 1999, pp. 372-4, considering that Amsterdam has brought limited progress in the area of transparency and accountability, whereas the degree of judicial control provided for under the Treaty of Amsterdam is less satisfactory.

${ }^{447}$ However, even the radical sceptic has to acknowledge that substantial integration is taking place in the area of deflective measures: as we will see below, visa requirements are harmonised to a large extent, and the allocation of responsibility for processing asylum claims is governed by common rules. 
Amsterdam and beyond. In the remaining chapters of Part II, we shall look into the normative world of the acquis as it stands today. The perspective of the protection seeker informs the order of presentation. First, we shall expound norms regulating access to territory (chapter 5); second, we will present norms regulating access to full-fledged procedures (chapter 6); and third, we shall proceed by expanding on those norms governing access to protection (chapter 7). The fourth and last step shall be an exploration of the issue of burden-sharing in the EU context (chapter 8). 